\title{
SISTEM INFORMASI REKAM MEDIS BERBASIS JARINGAN PADA PUSKESMAS LOA BAKUNG MENGGUNAKAN ASP.NET 3,5
}

\author{
Ita Arfyanti ${ }^{1)}$, Kusno Harianto ${ }^{2)}$, Dhanny Rindya Pradifta.AS ${ }^{3)}$ \\ ${ }^{1}$ Sistem Informasi, STMIK Widya Cipta Dharma \\ ${ }^{2,3}$ Teknik Informatika, STMIK Widya Cipta Dharma \\ E-mail : qonita23@yahoo.com ${ }^{1)}$, kusnoharianto97.kh@gmail.com ${ }^{2)}$,dhanierindya@gmail.com ${ }^{3)}$
}

\begin{abstract}
ABSTRAK
Rekam medis adalah berkas yang berisikan catatan dan dokumen tentang identitas pasien pemeriksaan, pengobatan, tindakan dan pelayanan lain yang telah diberikan kepada pasien. Dengan adanya penggunaan aplikasi rekam medis berbasis jaringan diharapkan dapat memperbaiki pengumpulan data dan pelaksanaan lainnya yang terkait di puskesmas.

Pada penelitian ini dibuat pada puskemas Loa Bakung untuk meningkatkan kualitas pelayanan. Aplikasi ini dibuat menggunakan ASP.NET 3.5. Metode pengembangan yang digunakan yaitu waterfall. Alat Bantu pengembangan sistem yang digunakan yaitu Flow Of Document (FOD), Data Flow Diagram (DFD), Hierarchy Plus Input Output (HIPO), dan Entity Relationship Diagram (ERD). Bahasa pemrograman yang digunakan C\# dan menggunakan SQL server.
\end{abstract}

Kata Kunci: Rekam Medis, ASP.NET., SQL server, C\#

\begin{tabular}{ll}
\hline 1. PENDAHULUAN & kondisi kesehatan dan penyakit pasien yang \\
Pembangunan nasional di ibukota Samarinda & $\begin{array}{l}\text { bersangkutan disebut patient record. Bagian kedua yaitu } \\
\text { tentang manajemen yaitu suatu informasi yang bisa }\end{array}$ \\
Propinsi Kalimantan Timur mengalami perkembangan & $\begin{array}{l}\text { dipertanggung jawabkan dari segi manajemen dan } \\
\text { penyakit pasien. } \\
\text { pesat untuk mencapainya diperlukan sumber daya }\end{array}$ \\
manusia yang tangguh dan mandiri serta berkualitas. Dan & Dengan adanya penggunaan aplikasi rekam medis \\
upaya peningkatan kualitas sumber daya yang harus & berbasis jaringan diharapkan dapat memperbaiki \\
dilakukan salah satunya ialah menunjang peranan & pengumpulan data dan pelaksanaan lainnya yang terkait \\
keberhasilan pembangunan kesehatan. Penduduk yang & di puskesmas. Serta dapat menghubungkan komputer di \\
sehat tidak hanya meningkatkan pendidikan tetapi & ruang yang satu dengan lainnya sehingga lebih \\
mendorong produktivitas dan pendapatan masyarakat. & komunikatif, efektif, akurat, up to date berkenaan data \\
Untuk mempercepat keberhasilan pembangunan & pasien, ketersediaan obat, penyakit dan sebagainya. Dan \\
kesehatan maka diperlukan suatu kebijakan yang & masyarakat pun mendapat pelayanan yang lebih baik dari \\
meningkatkan kinerja sektor kesehatan dan paradigma & puskesmas yang bersangkutan.
\end{tabular}
mereformasi pelayanan kesehatan di daerah masingmasing sesuai dengan kewenangannya sendiri yaitu dengan membuat aplikasi rekam medis berbasis jaringan di puskesmas Loa Bakung.

Kegiatan rekam medis pada puskesmas Loa Bakung masih jauh dari kata akurat dan sistematis, selain masih tidak terkomputerisasi, penyimpanan data masih dalam bentuk arsip buku, sehingga ketika mencari data yang dibutuhkan memakan waktu lama. Selain itu untuk kegiatan tertentu misal membuat surat ijin sakit atau surat kesehatan, bagian administrasi yang berada di lantai 1 harus pergi memberikan data pada bagian Tata Usaha (TU) di lantai 2. Kegiatan ini tanpa sadar membuat antrian pasien semakin banyak, memakan waktu dan apabila terjadi kesalahan pada data maka pegawai Tata Usaha (TU) harus memperbaiki ulang. Karena itu peneliti ingin membuat suatu aplikasi rekam medis yang berbasis jaringan, hal ini akan sangat membantu pelaksanaan pelayanan sehingga lebih mudah, efektif dan efisien.

Rekam medis mempunyai 2 bagian penting yaitu pertama tentang individu, suatu informasi tentang

\section{RUANG LINGKUP PENELITIAN}

1. Rumusan Masalah

Rumusan masalah yang dapat diangkat dari latar belakang yang ada yaitu "Bagaimana membuat perangkat lunak rekam medis pada Puskesmas Loa Bakung berbasis jaringan menggunakan pemrograman ASP.NET 3.5."

\section{Batasan Masalah}

Ruang lingkup batasan masalah penelitian ini difokuskan pada pembuatan aplikasi rekam medis berbasis jaringan pada puskesmas Loa Bakung menggunakan pemrograman ASP.NET 3.5. dan beberapa batasan masalah antara lain :

1. Aplikasi berisi :

1) Pendaftaran pasien baru.

2) Pendaftaran pasien berobat.

3) Data pasien.

4) Data poli.

5) Data dokter.

6) Data obat. 
7) Data diagnosa rekam medis.

8) Data laporan rekam medis.

2. Hak Akses :

1) Admin

(1) Input data master yang meliputi input data dokter dan data poli.

(2) Mengolah laporan yang meliputi laporan data pasien, laporan data obat, laporan dokter dan laporan rekam medis.

2) Loket

(1) Input data pendaftaran pasien baru.

(2) Input data pendaftaran pasien berobat.

(3) Sistem memberikan nomor antrian.

3) Dokter

Dokter melakukan proses diagnosa rekam medis dengan memasukkan hasil diagnosa dan memasukkan obatnya.

4) Apotik

Apotik memasukkan data obat di master obat dan proses pengeluaran obat

3. Sistem dapat memberikan laporan rekam medis pasien.

4. Sistem dapat memberikan laporan data pasien.

5. Sistem dapat memberikan laporan data obat.

6. Sistem dapat memberikan laporan data dokter.

7. Sistem digunakan untuk poli gigi dan umum.

8. Sistem tidak menyediakan surat rujukan pasien ke rumah sakit atau instansi kesehatan lainnya.

9. Sistem tidak menyediakan kartu berobat.

10. Sistem tidak menyediakan sistem pembayaran.

11. Sistem tidak menyediakan informasi rawat inap.

\section{BAHAN DAN METODE}

\subsection{Rekam Medis}

Menurut Permenkes No.269 / Menkes / Per / III / 2008, rekam medis adalah berkas yang berisikan catatan dan dokumen tentang identitas pasien pemeriksaan, pengobatan, tindakan dan pelayanan lain yang telah diberikan kepada pasien.

Menurut Gondodiputro (2007), rekam medis adalah keterangan baik yang tertulis maupun yang terekam tentang identitas, anamnesa, penentuan fisik, laboratorium, diagnosa segala pelayanan dan tindakan medik yang diberikan kepada pasien dan pengobatan baik yang dirawat inap, rawat jalan maupun yang mendapat pelayanan gawat darurat.

Pada prinsipnya, tujuan rekam medis adalah untuk menunjang tercapainya tertib administrasi dalam rangka upaya peningkatan pelayanan kesehatan.

\subsection{Metode Pengembangan Sistem}

Menurut Rosa dan Shalahuddin (2011, hal 24), Metode pengembangan adalah proses mengembangkan atau mengubah suatu sistem perangkat lunak dengan menggunakan modelmodel dan metodologi yang digunakan orang untuk mengembangkan sistem-sistem perangkat lunak sebelumnya (berdasarkan best practice atau caracara yang sudah teruji baik).

Macam-macam metode pengembangan rekayasa perangkat lunak antara lain : waterfall, prototyping, RAD, OOD, dan OMT. Masingmasing mempunyai kelebihan dan kelemahan sendiri.

1. Waterfall

Metode ini merupakan metode yang sering digunakan oleh penganalisa sistem pada umumnya. Inti dari metode waterfall adalah pengerjaan dari suatu sistem dilakukan secara berurutan atau secara linear. Jadi jika langkah satu belum dikerjakan maka tidak akan bisa melakukan pengerjaan langkah 2, 3 dan seterusnya. Secara otomatis tahapan ke-3 akan bisa dilakukan jika tahap ke-1 dan ke-2 sudah dilakukan.

2. Protyping

Metode ini sering digunakan pada dunia riil. Karena metode ini secara keseluruhan akan mengacu kepada kepuasan user. Bisa dikatakan bahwa metode ini merupakan metode waterfall yang dilakukan secara berulang-ulang.

\section{RANCANGAN SISTEM/APLIKASI}

1. Flow Of Document (FOD) yang berjalan di Puskesmas Loa Bakung

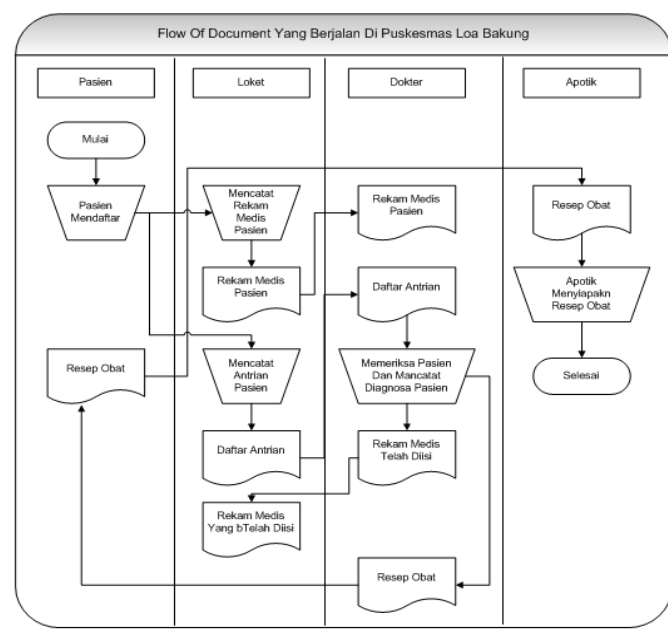

\section{Gambar 1. FOD Yang Berjalan}

Gambar 1 merupakan flow of document (FOD) Puskesmas Loa Bakung pada sistem berjalan yang menjelaskan sebagai berikut :

Pertama pasien datang ke bagian loket untuk mendaftar dan mendapat nomor antrian. Kemudian petugas admin mencatat data rekam medis dan nomor antrian pasien serta menyampaikan daftar antrian pasien dan data 
rekam medis kepada bagian dokter. Dokter memberikan tindakan medis dan pengobatan kepada pasien, kemudian mencatat diagnosa penyakit dan resep obat yang diberikan kedalam data rekam pasien. Seterusnya pasien membawa resep obat ke apotik untuk mengambil obat.

2. Flow Of Document (FOD) yang diusulkan.

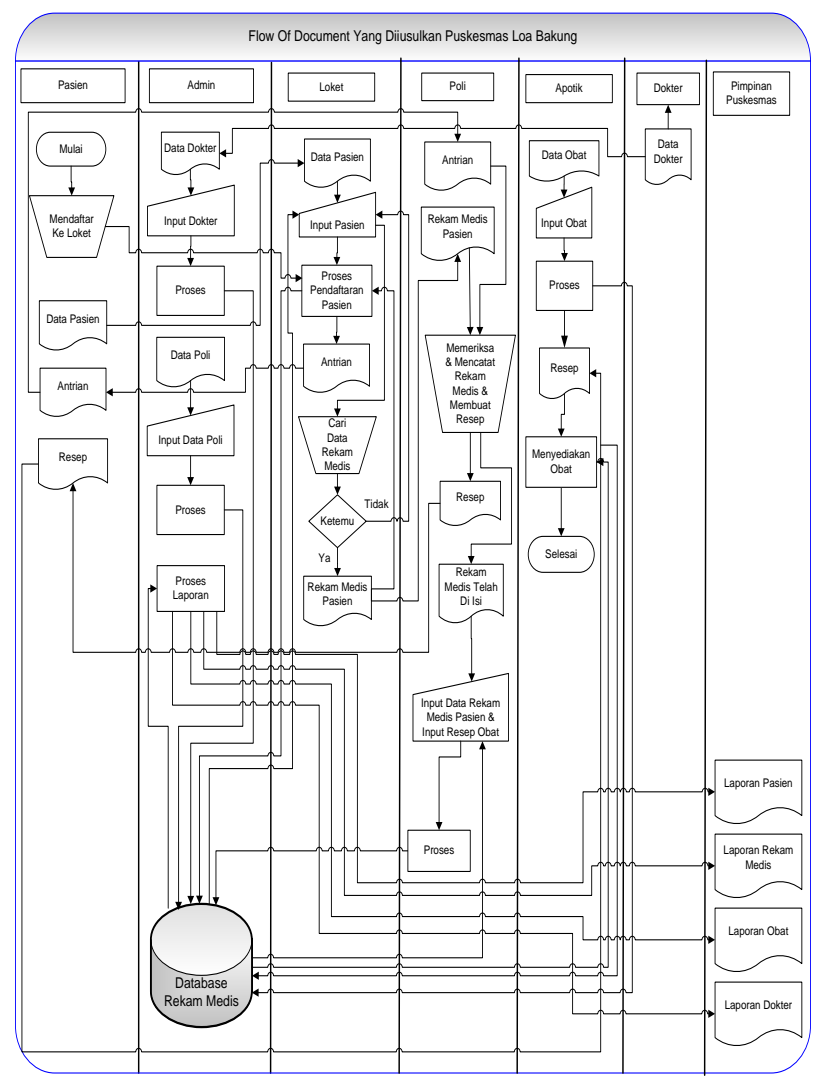

Gambar 2. FOD Yang Diusulkan

Gambar 2 merupakan Flow Of Document (FOD) sistem informasi rekam medis pada puskesmas Loa Bakung pada sistem yang diusulkan dijelaskan sebagai berikut :

Pasien datang ke puskesmas Loa Bakung ke bagian loket pendaftaran sambil menunjukkan kartu berobat. Kemudian admin loket menginputkan data pasien yang mendaftar kedalam sistem. Setelah itu pasien mengambil nomor antrian kemudian pergi ke bagian poli, dokter membuka sistem dan membuka daftar nama pasien yang akan berobat. Setelah itu pasien diberikan pengobatan dan dokter menginputkan data dalam sistem dan memberikan resep. Pasien menerima resep dan mengambil obat ke apotik, bagian apotik memeriksa stok obat dan obat diberikan ke pasien.

\section{Context Diagram (CD)}

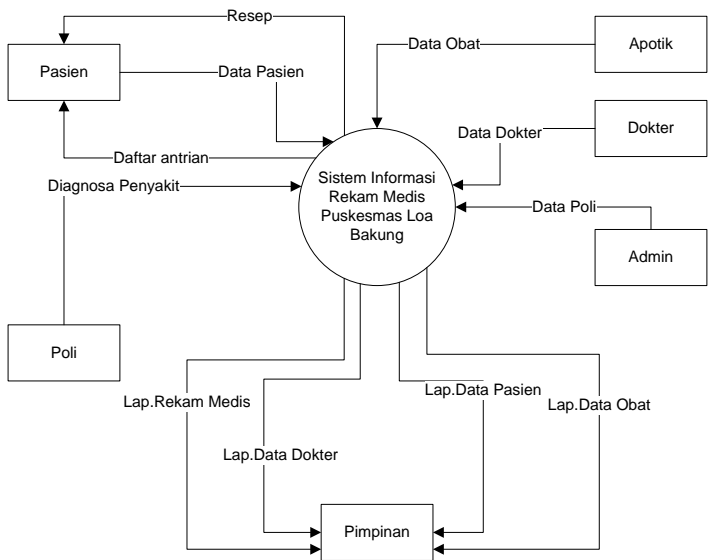

Gambar 3. Konteks Diagram Sistem

Gambar 3 menjelaskan terdapat 5 buah entitas yang mempunyai peran dalam membentuk sistem informasi rekam medis pada puskesmas. Entitas tersebut adalah admin, apotik, dokter, pasien dan pimpinan puskesmas yang bersangkutan.

\section{Data Flow Diagram (DFD) Level 0}

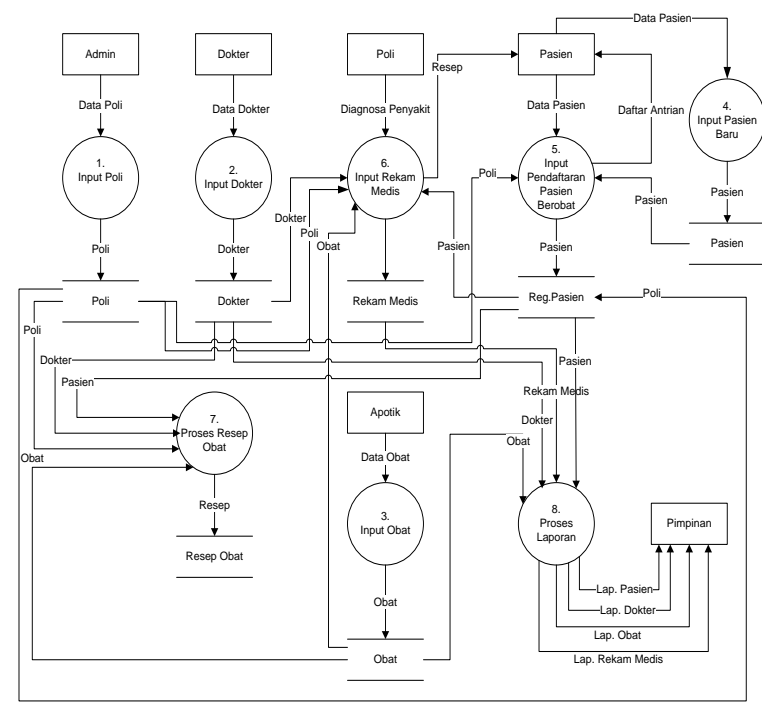

Gambar 4. DFD Level 1

Gambar 4 menjelaskan terdapat lima entitas yaitu pasien, dokter, apotik, admin dan pimpinan puskesmas serta terdapat enam proses yang terjadi pada sistem. Proses pertama yaitu admin memasukkan data poli dan disimpan kedalam tabel poli. Proses kedua yaitu entitas dokter memberikan data dokter dan disimpan dalam tabel dokter. Proses ketiga adalah apotik memberikan data obat kedalam sistem dan disimpan kedalam tabel obat. Proses keempat dan enam entitas pasien memberikan data pasien kemudian disimpan dalam tabel pasien baru serta pendaftaran pasien berobat. Proses keenam yaitu 
melibatkan tabel dokter, tabel, pasien, tabel obat dan tabel rekam medis itu sendiri. Proses ketujuh merupakam proses resep. Proses kedelapan adalah pelaporan rekam medis yang ditujukan kepada pimpinan puskesmas.

5. Data Flow Diagram (DFD) Level 1

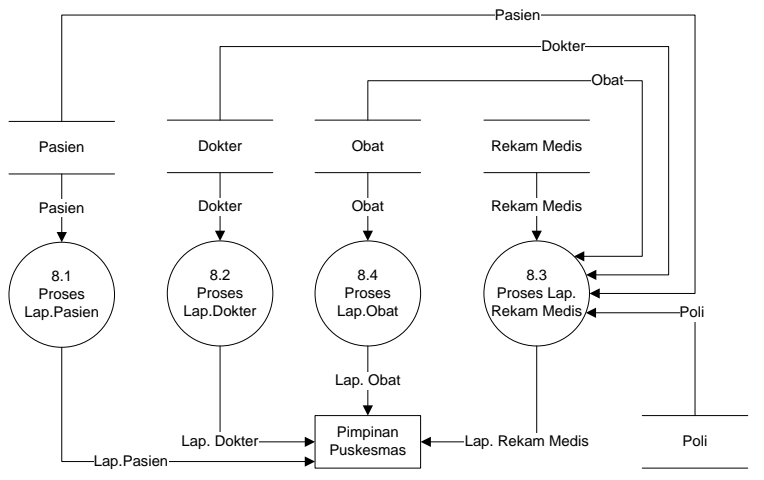

Gambar 5. DFD Level 0

Gambar 5 menjelaskan Data Flow Diagram (DFD) Level 1 terdapat 4 proses laporan yaitu laporan pasien, laporan dokter, laporan obat dan laporan rekam medis. Pada proses laporan pasien data diperoleh dari data store pasien dan menghasilkan laporan pasien yang diberikan kepada entitas pimpinan. Pada proses laporan dokter data diperoleh dari data store dokter dan menghasilkan laporan yang diberikan kepada pimpinan. Pada proses laporan obat data diperoleh dari data store obat dan menghasilkan laporan yang diberikan kepada entitas pimpinan. Pada proses laporan rekam medis diperoleh dari data store poli, doker, obat dan pasien menghasilkan laporan yang diberikan kepada entitas pimpinan.

6. HIPO

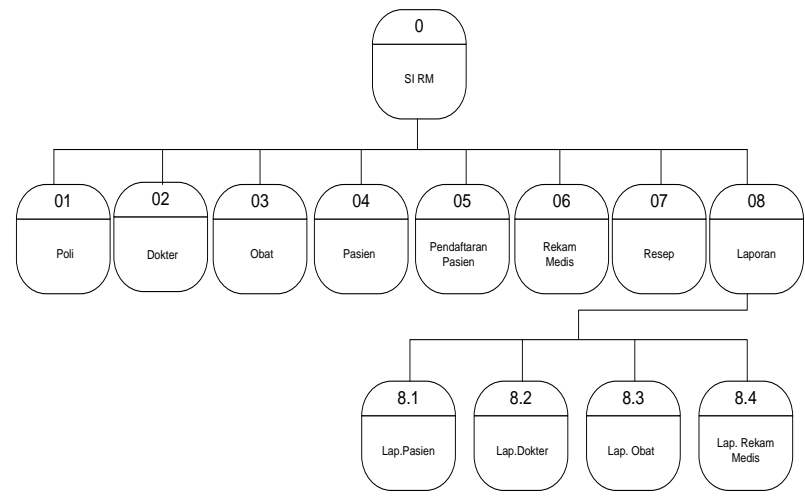

Gambar 6. HIPO

Pada gambar 6 menjelaskan diagram dari Hierarchy Input Process Output (HIPO) dari sistem informasi rekam medis puskesmas Loa Bakung.

\section{Relasi Tabel}

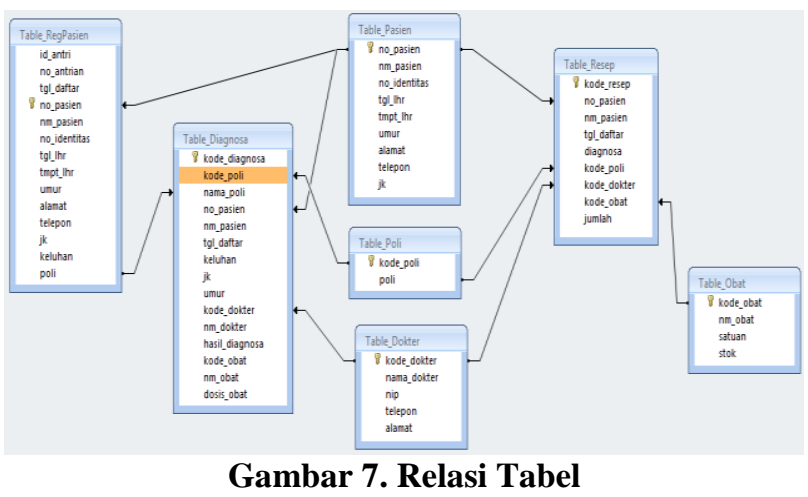

Gambar 7 pada sistem informasi rekam medis pada puskesmas Loa Bakung menjelaskan terdapat 8 tabel utama. Tabel-tabel tersebut adalah tabel pasien, tabel dokter, tabel obat, tabel poli, tabel regpasien, tabel diagnosa rekam medis dan tabel resep

\section{IMPLEMENTASI}

Perangkat lunak yang digunakan pada sistem ini adalah ASP.NET 3,5 yang merupakan modulator untuk pembuatan aplikasi dengan basis web dinamis untuk aplikasi desktop sedangkan bahasa pemrograman yang digunakan adalah C\#. Untuk database digunakan SQL Server 2005.

1) Tabel Pendaftaran Pasien Baru

Tabel ini digunakan untuk menampung semua data pasien yang baru.

Nama Tabel : Tabel Pasien

Field Kunci : No_pasien

Tabel 1. Desain tabel pasien

\begin{tabular}{|l|l|l|c|}
\hline Field Name & Type & Width & Description \\
\hline No_pasien & Varchar & 10 & Kode pasien \\
\hline Nama_pasien & Varchar & 100 & Nama pasien \\
\hline No_Identitas & Varchar & 30 & No identitas \\
\hline Tgl_lahir & Date & $\begin{array}{c}\text { Tanggal lahir } \\
\text { pasien }\end{array}$ \\
\hline Tmpt_lahir & Varchar & 50 & $\begin{array}{c}\text { Tempat lahir } \\
\text { pasien }\end{array}$ \\
\hline Umur & Int & Umur \\
\hline Alamat & Varchar & 100 & Alamat pasien \\
\hline Telepon & Varchar & 15 & Telepon \\
\hline JK & Varchar & 10 & Jenis kelamin \\
\hline
\end{tabular}

2) Tabel Pendaftaran Pasien Berobat

Tabel ini digunakan untuk menampung pendaftaran pasien berobat.

Nama Tabel : Tabel Regpasien

Field Kunci : No_pasien

Tabel 2. Desain tabel regpasien

\begin{tabular}{|l|l|l|l|}
\hline Field Name & Type & Width & Description \\
\hline Id_antri & Int & & Kode antri \\
\hline No_antrian & Varchar & 10 & $\begin{array}{l}\text { Nomor } \\
\text { antrian }\end{array}$ \\
\hline
\end{tabular}




\begin{tabular}{|l|l|l|c|}
\hline Tgl_daftar & Date & $\begin{array}{l}\text { Tanggal } \\
\text { daftar }\end{array}$ \\
\hline No_pasien & Varchar & 10 & Kode pasien \\
\hline Nama_pasien & Varchar & 100 & Nama pasien \\
\hline No_Identitas & Varchar & 30 & No identitas \\
\hline Tgl_lahir & Date & $\begin{array}{c}\text { Tanggal lahir } \\
\text { pasien }\end{array}$ \\
\hline Tmpt_lahir & Varchar & 50 & $\begin{array}{c}\text { Tempat lahir } \\
\text { pasien }\end{array}$ \\
\hline Umur & Int & & Umur \\
\hline Alamat & Varchar & 100 & Alamat pasien \\
\hline Telepon & Varchar & 15 & Telepon \\
\hline JK & Varchar & 10 & Jenis kelamin \\
\hline Keluhan & Varchar & 100 & Keluhan \\
\hline Poli & Varchar & 12 & Poli \\
\hline
\end{tabular}

3) Tabel Poli

Tabel ini digunakan untuk menampung data poli.

Nama Tabel : Tabel Poli

Field Kunci : Kode_poli

Tabel 3. Desain tabel poli

\begin{tabular}{|l|l|l|c|}
\hline $\begin{array}{l}\text { Field } \\
\text { Name }\end{array}$ & Type & Width & Description \\
\hline Kode_poli & Varchar & 10 & Kode poli \\
\hline Nama_poli & Varchar & 50 & Nama poli \\
\hline
\end{tabular}

4) Tabel Dokter

Tabel ini digunakan untuk menampung data dokter.

Nama Tabel: Tabel Dokter

Field Kunci : Kode_dokter

Tabel 4. Tabel dokter

\begin{tabular}{|l|l|l|c|}
\hline Field Name & Type & Width & Description \\
\hline Kode_dokter & Varchar & 10 & Kode dokter \\
\hline Nama_dokter & Varchar & 100 & Nama dokter \\
\hline Nip & Varchar & 50 & NIP \\
\hline Telepon & Varchar & 15 & Telepon \\
\hline Alamat & Varchar & 100 & Alamat \\
\hline
\end{tabular}

5) Tabel Obat

Tabel ini digunakan untuk menampung data obat

Nama Tabel: Tabel Obat

Field Kunci : Kode_obat

Tabel 5. Tabel obat

\begin{tabular}{|l|l|l|c|}
\hline $\begin{array}{l}\text { Field } \\
\text { Name }\end{array}$ & Type & Width & Description \\
\hline Kode_obat & Varchar & 10 & Kode obat \\
\hline Nama_obat & Varchar & 50 & Nama Obat \\
\hline Satuan & Varchar & 50 & Satuan \\
\hline Jumlah & Int & & Jumlah Obat \\
\hline
\end{tabular}

Tabel 6. Tabel diagnosa

\begin{tabular}{|c|c|c|c|}
\hline Field Name & Type & Width & Description \\
\hline Kode diagnosa & Int & & $\begin{array}{c}\text { Kode } \\
\text { Diagnosa } \\
\end{array}$ \\
\hline Kode_poli & Varchar & 10 & Kode Poli \\
\hline Nama_poli & Varchar & 50 & Nama Poli \\
\hline No_pasien & Varchar & 10 & Kode Pasien \\
\hline Nama_pasien & Varchar & 100 & Nama Pasien \\
\hline Tgl_dftr & $\begin{array}{l}\text { Date/Ti } \\
\text { me }\end{array}$ & & $\begin{array}{c}\text { Tanggal } \\
\text { Daftar } \\
\end{array}$ \\
\hline Keluhan & Text & & Keluhan \\
\hline JK & Varchar & 10 & $\begin{array}{c}\text { Jenis } \\
\text { Kelamin }\end{array}$ \\
\hline Umur & Int & & $\begin{array}{c}\text { Umur } \\
\text { Pasien } \\
\end{array}$ \\
\hline Kode_dokter & Varchar & 10 & Kode Dokter \\
\hline Nama_poli & Varchar & 50 & Nama Poli \\
\hline Nama_dokter & Varchar & 100 & $\begin{array}{l}\text { Nama } \\
\text { Dokter }\end{array}$ \\
\hline $\begin{array}{l}\text { Hasil_Diagnos } \\
\text { a }\end{array}$ & Text & & $\begin{array}{c}\text { Hasil } \\
\text { Diagnosa } \\
\text { Dokter }\end{array}$ \\
\hline Kode_obat & Varchar & 10 & Kode Obat \\
\hline Nm_obat & Varchar & 50 & Nama Obat \\
\hline Dosis Obat & Int & & Jumlah Obat \\
\hline
\end{tabular}

7) Tabel Resep

Tabel ini digunakan untuk menampung data obat

Nama Tabel : Tabel Resep

Field Kunci : Kode_resep

Tabel 7. Tabel resep

\begin{tabular}{|l|l|l|c|}
\hline Field Name & Type & Width & Description \\
\hline Kode resep & Varchar & 10 & Kode resep \\
\hline No_pasien & Varchar & 10 & No pasien \\
\hline Nama_pasien & Varchar & 100 & Nama pasien \\
\hline Tgl_dftr & Date/Time & & $\begin{array}{c}\text { Tanggal } \\
\text { Daftar }\end{array}$ \\
\hline Diagnosa & Text & & Diagnosa \\
\hline Kode_poli & Varchar & 10 & Nama Poli \\
\hline Kode_dokter & Varchar & 10 & Kode dokter \\
\hline $\begin{array}{l}\text { Hasil } \\
\text { Diagnosa }\end{array}$ & Text & & Diagnosa \\
\hline Kode_obat & Varchar & 10 & Kode obat \\
\hline Jumlah & Int & & Jumlah obat \\
\hline Field Name & Type & Width & Description \\
\hline Kode_obat & Varchar & 10 & Kode obat \\
\hline Nama_obat & Varchar & 50 & Nama Obat \\
\hline Satuan & Varchar & 50 & Satuan \\
\hline Jumlah & Int & & Jumlah Obat \\
\hline
\end{tabular}

6) Tabel Rekam Medis

Tabel ini digunakan untuk menampung data diagnosa rekam medis.

Nama Tabel: Tabel Diagnosa

Field Kunci : Kode_diagnosa 
8) Tampilan Form Login

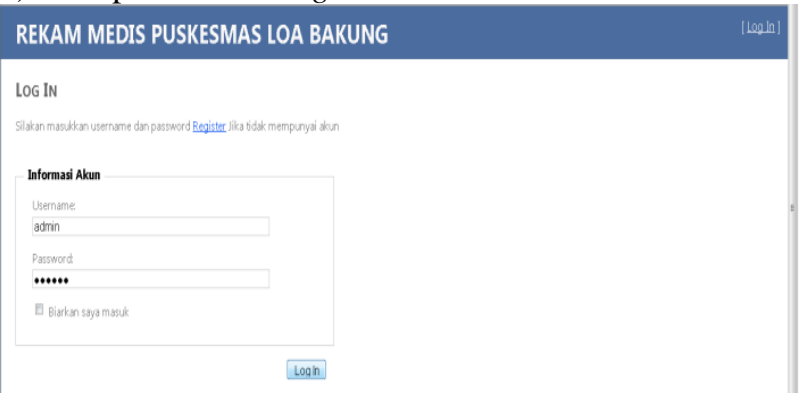

Gambar 8. Halaman login

9) Tampilan Form Pendaftaran Pasien baru

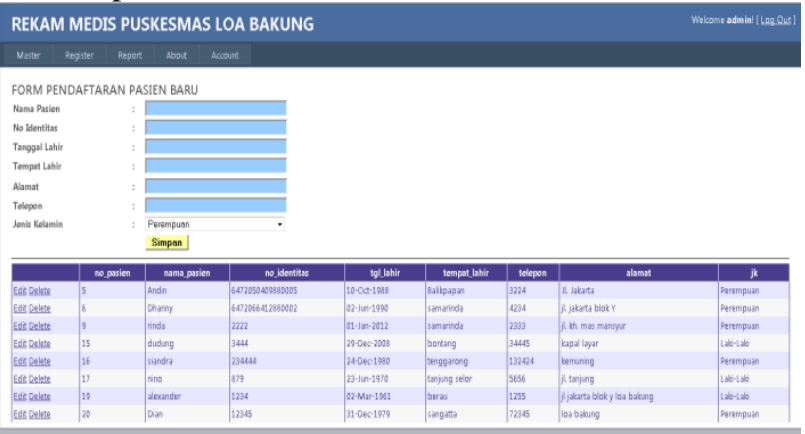

Gambar 9. Halaman pendaftaran pasien baru

10)Tampilan Form Pendaftaran Pasien Berobat

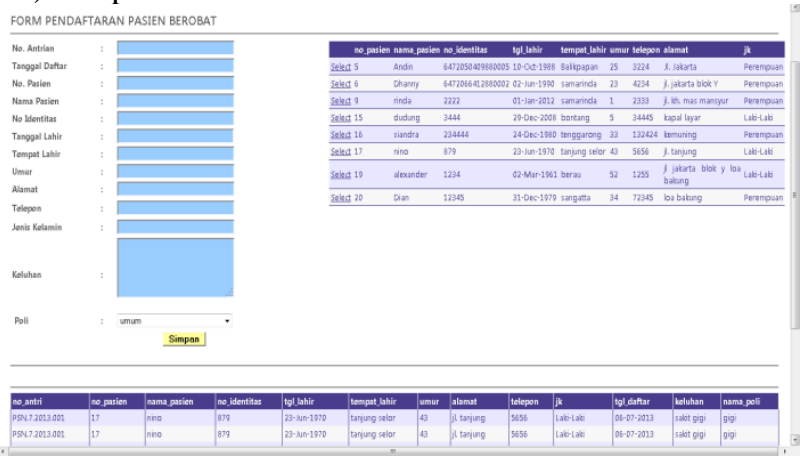

Gambar 10. Halaman pendaftaran pasien berobat

11)Tampilan Laporan Rekam Medis Pasien

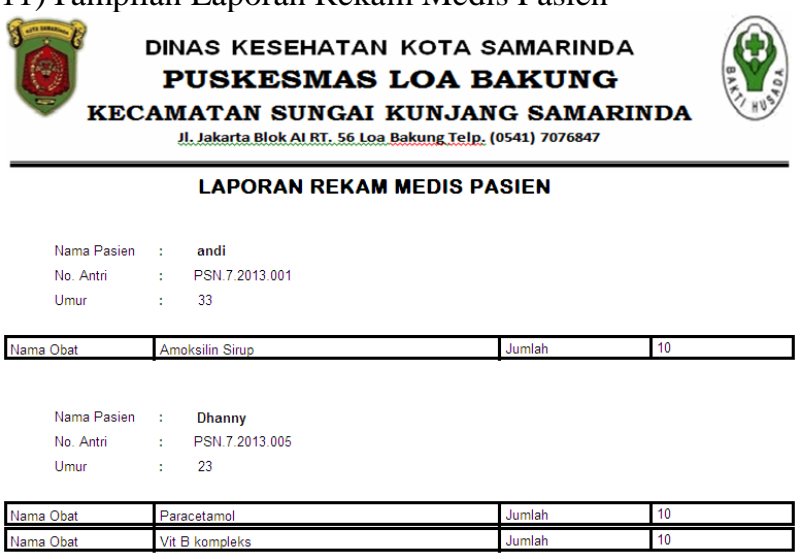

Gambar 11. Laporan Rekam Medis Pasien

\section{KESIMPULAN}

Dari permasalahn yang ada penulis memberikan kesimpulan mengenai mekanisme pendaftaran pasien berobat sampai dengan pemberian resep obat di Puskesmas Loa Bakung sebagai berikut :

1. Pasien datang mendaftar hingga di periksa oleh dokter dan resep obat yang diberikan terekam dalam database digital sehingga memudahkan dalam pencarian dan pengolahahnya.

2. Mendapatkan data yang akurat dan update karena data rekam medis tersimpan dalam database.

\section{SARAN}

Untuk membangun aplikasi ini yang lebih baik penulis memberikan saran yang sekiranya dapat membantu mengurangi masalah pada Puskesmas Loa Bakung, antara lain :

1. Dapat menampilkan data pasien secara detail dalam satu form.

2. Peneliti mengharapkan sistem yang dibuat dapat diimplementasikan dan menyumbangkan kontribusi positif dalam meningkatkan pelayanan kesehatan masyarakat.

3. Harapan untuk peneliti yang akan mengembangkan penelitian ini agar dapat melengkapi kekurangan aplikasi ini dan dapat diimplementasikan lebih dari 2 poli serta laporanlaporan baik kartu berobat pasien dan surat rujukan bisa di buat secara otomatis.

\section{DAFTAR PUSTAKA}

Aditya, Alan Nur, 2011, 30 Menit Mahir Membuat Jaringan Komputer, Jakarta : Dunia Komputer

Huda, Miftahul, 2009, Membuat Aplikasi Rental Dengan Java Dan My $S Q L$, Jakarta : PT Elex Media Komputindo

Jogiyanto, HM, 2005, Analisis Sistem Informasi Pendekatan Terstruktur Teori Dan Aplikasi Bisnis, Jakarta

Kurniawan, Erick, 2012, Pemrograman Web Dinamis Dengan ASP.NET 4.5, Yogyakarta: Andi.

Kurniawan, Erick, 2010, Cepat Mahir ASP.NET 3.5 Untuk Aplikasi Web Interaktif, Yogyakarta: Andi.

Nugroho, Adi, 2011, Visual Web Developer Untuk Pengembangan Aplikasi Web

Dinamis, Yogyakarta : Andi.

Shalahuddin, M dan Rosa, A.S. 2011, Modul Pembahasan Rekayasa Perangkat Lunak (Terstruktur Dan Berorientasi Objek), Bandung : Modula 